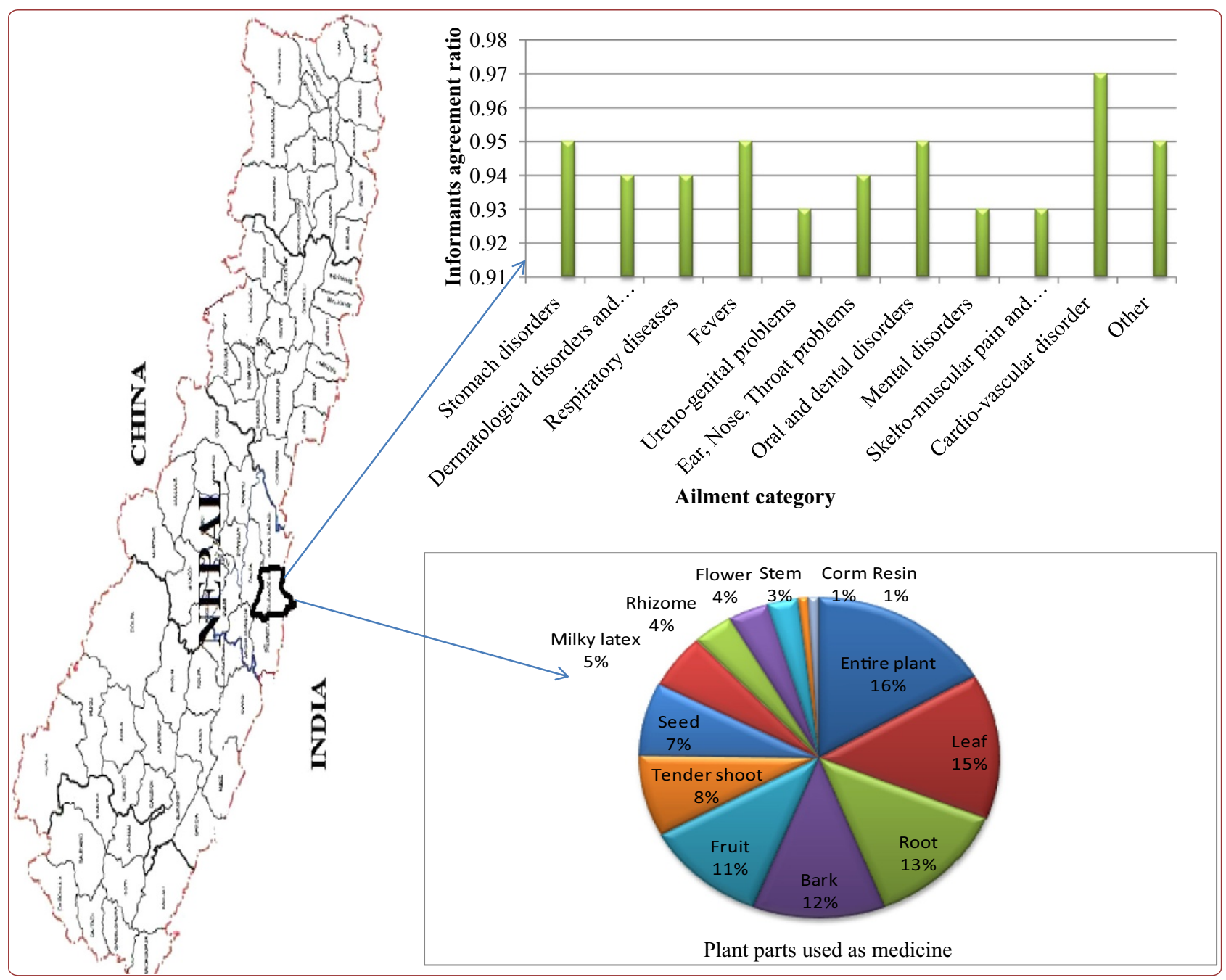

\title{
An ethnobotanical survey of medicinal plants used in Terai forest of western Nepal
}

Singh et al. 


\title{
An ethnobotanical survey of medicinal plants used in Terai forest of western Nepal
}

\author{
Anant Gopal Singh ${ }^{1 *}$, Akhilesh Kumar ${ }^{2}$ and Divya Darshan Tewari ${ }^{3}$
}

\begin{abstract}
Background: Nepal Himalayas have been known as a rich source for valuable medicinal plants since Vedic periods. Present work is the documentation of indigenous knowledge on plant utilization as natural remedy by the inhabitants of terai forest in Western Nepal.

Methods: Study was conducted during 2010-2011 following standard ethnobotanical methods. Data about medicinal uses of plants were collected by questionnaire, personal interview and group discussion with pre identified informants. Voucher specimens were collected with the help of informants, processed into herbarium following standard methods, identified with the help of pertinent floras and taxonomic experts, and submitted in Department of Botany, Butwal Multiple Campus, Tribhuvan University, Nepal for future references.

Results: During the present study 66 medicinal plant species belonging to 37 families and 60 genera has been documented. These plants were used to treat various diseases and ailments grouped under 11 disease categories, with the highest number of species (41) being used for gastro-intestinal disorders, followed by dermatological disorders (34). In the study area the informants' consensus about usages of medicinal plants ranges from 0.93 to 0.97 with an average value of 0.94 . Herbs (53\%) were the primary source of medicine, followed by trees (23\%). Curcuma longa (84\%) and Azadirachta indica (76\%) are the most frequently and popularly used medicinal plant species in the study area. Acacia catechu, Bacopa monnieri, Bombax ceiba, Drymaria diandra, Rauvolfia serpentina, and Tribulus terrestris are threatened species which needs to be conserved for future use.
\end{abstract}

Conclusions: The high degree of consensus among the informants suggests that current use and knowledge are still strong, and thus the preservation of today's knowledge shows good foresight in acting before much has been lost. The connections between plant use and conservation are also important ones, especially as the authors note that neither the local inhabitants nor the government is addressing the potential loss of valuable species in this region.

Keywords: Ethnobotany, Medicinal plants, Traditional healers, Tharu, Magar, Terai forest, Nepal

\section{Background}

The Rig-Veda written during $4500 \mathrm{BC}$ to $1600 \mathrm{BC}$ is believed to be the oldest repository of human knowledge about medicinal usages of plants in Indian subcontinent. In Nepal, although such old documentation is still not rediscovered, but the knowledge on plant utilization is believed to be very old. According to WHO [1], about $80 \%$ of the world's population, especially in the rural areas depends on herbal medicine for their healthcare needs. About $90 \%$ of the Nepalese people reside in rural areas where access to government health care facilities is

\footnotetext{
*Correspondence: agsingh26@rediffmail.com

'Department of Botany, Butwal Multiple Campus, Tribhuvan University, Tribhuvan, Nepal

Full list of author information is available at the end of the article
}

lacking [2]. The ethnic people residing in different geographical belts of Nepal depends on wild plants to meet their basic requirements and all the ethnic communities have their own pool of secret ethnomedicinal and ethnopharmacological knowledge about the plants available in their surroundings [2-20], which has been serving rural people with its superiority. Due to changing life style, extreme secrecy of traditional healers and negligence of youngsters, the practice and dependence of ethnic societies in folk medicines is in rapid decline globally, therefore, ethnobotanical exploitation and documentation of indigenous knowledge about the usefulness of such a vast pool of genetic resources is deliberately needed [2130]. We selected Terai forest of Rupandehi district and 
adjoining areas for ethnomedicinal investigation because this area is very rich in phytodiversity and tribal population. Besides other usages of plants the practice of oral tradition for healthcare management of human and domesticated animals using herbal medicines is still prevalent among the inhabitants of the area. They have enormous knowledge about medicinal uses of plants and this knowledge is mostly undocumented and transmitted orally from generation to generation. Recently due to unplanned developmental programs, increasing modern healthcare facilities and impact of modern civilization in this area, natural resources as well as traditional knowledge and tribal cultures are depleting rapidly at an alarming rate. Therefore, it is urgent to explore and document this unique and indigenous, traditional knowledge of the tribal community, before it diminishes with the knowledgeable persons. Further, documentation of indigenous and traditional knowledge is very important for future critical studies leading to sustainable utilization of natural resource and to face the challenges of biopiracy and patenting indigenous and traditional knowledge by others. Besides, to the best of our knowledge no ethnobotanical work has been carried out in this area. Keeping these things in mind present study was proposed to document the ethnomedicinal knowledge in terai forest of western Nepal. Aims of the present study are:

(A) Identification and documentation of plant species used for the treatment and prevention of various diseases and ailments in the study area.

(B) Identification of most common and popularly used medicinal plant species for the treatment and prevention of various diseases and ailments in the study area.

(C) Find out the level of consensus agreement between the informants regarding the uses of particular medicinal plant(s) for the treatment of particular disease category.

\section{Study area}

Rupandehi district is situated in the Terai region of western Nepal. It lies between $83^{0} 27^{\prime} .955^{\prime \prime}$ to $83^{\circ} 28^{\prime} .255^{\prime \prime} \mathrm{E}$ and $27^{\circ} 40^{\prime} .016^{\prime \prime}$ to $27^{\circ} 40^{\prime} .252^{\prime \prime} \mathrm{N}$ geographical limits in $1360 \mathrm{Km}^{2}$ area at altitudinal variation from 105 to 258 meters. Rupandehi district (Figure 1) is surrounded by hilly districts (Palpa and Arghakhanchi) in North, by Mahrajganj district of Uttar Pradesh (India) in south, by Nawalparasi district in East and by Kapilvastu district in west. It has tropical climate with maximum temperature beyond $40^{\circ} \mathrm{C}$ during summer (May- June) and below $10^{\circ} \mathrm{C}$ during winter (December- January) and annual rainfall is about $1250 \mathrm{~mm}$. Geographically, it is divided into Chure region (14.5\%); Bhabar region $(0.6 \%)$ and
Terai region (84.9\%). The famous river and rivulets of this district are Tinau, Rohini, Danaw, Pahela, Kanchan, Kothi, Danda, Koili etc. All the rivers flow from north to south. The climatic condition of the study site is tropical type and predominated by Sal forest. The forest area of the district is divided into community forest, religious forest and personal forest [31]. The vegetation of the study is dominated by sal (Shorea robusta) forest along with sissoo (Dalbergia sissoo), saj (Terminalia alata) khayar (Acacia catechu), baheda (Terminalia bellirica), dabdabe (Garuga pinnata), khaniyu (Ficus semicordata), asuro (Justica adhatoda), dhaiyaro (Woodfordia fruti$\cos a$ ), and titepati (Artemesia indica) etc. The main highway Siddhartha Rajmarga runs from the middle part of Shankar Nagar VDC. All the parts of Shankar Nagar VDC and its surrounding areas are interconnected by network of road and are easily accessible for the field visits.

\section{Ethnography}

The Tharu and the Magar are the main ethnic societies of the study area. They live in association with Chhetri, Brahmin, Thakuri, Gurung, Damai, Kumal, Bote, Majhi, Mushahar, Kami, Newar and others communities. Total population of the district was 7, 08,419 [32] The Tharu tribal community share $10.57 \%$ population of the district [31]. They are scattered all along the southern foot hills of the Himalayas. The greater parts of their population resides in Nepal, although they are also scattered in the adjacent Indian district of Champaran, Maharajganj, Gorakhpur, Siddharthnagar, Basti, Balrampur, Baharaich, Shravasti, Lakhimpur-Kheri, and Nainital. There are several endogamous sub groups in the Tharu community, such as Rana, Kathuria, Dangauria, Kochila, and Mech. Tharu people choose plain lands at the jungle side or river side for house construction. They like to settle in the group of their own community members, thus their houses are found dense within a small area. Tharu people used to live in joint family traditionally and it is practiced up to now. In Tharu village, the duty of maintaining good relations among villagers, as well as conducting the village's affairs, falls on the Mahaton (Village chief). A mahaton is elected by Gardhurryas (Tharu house hold chief) from among themselves. A Mahaton is elected, but once elected; the office becomes hereditary, unless a particular incumbent is considered a misfit. The assembly of Gardhurryas can remove an unsuccessful Mahaton. The role of mahaton in the assembly of Gardhurryas is like that of a chairman and a judge who keep others view in mind, gives the final communal decision. Due to their own believes, judgement policy and living together in close vicinity, they are considered as native Tribal community of Terai region. In Nepal Tharu tribal community is settled in the southern 


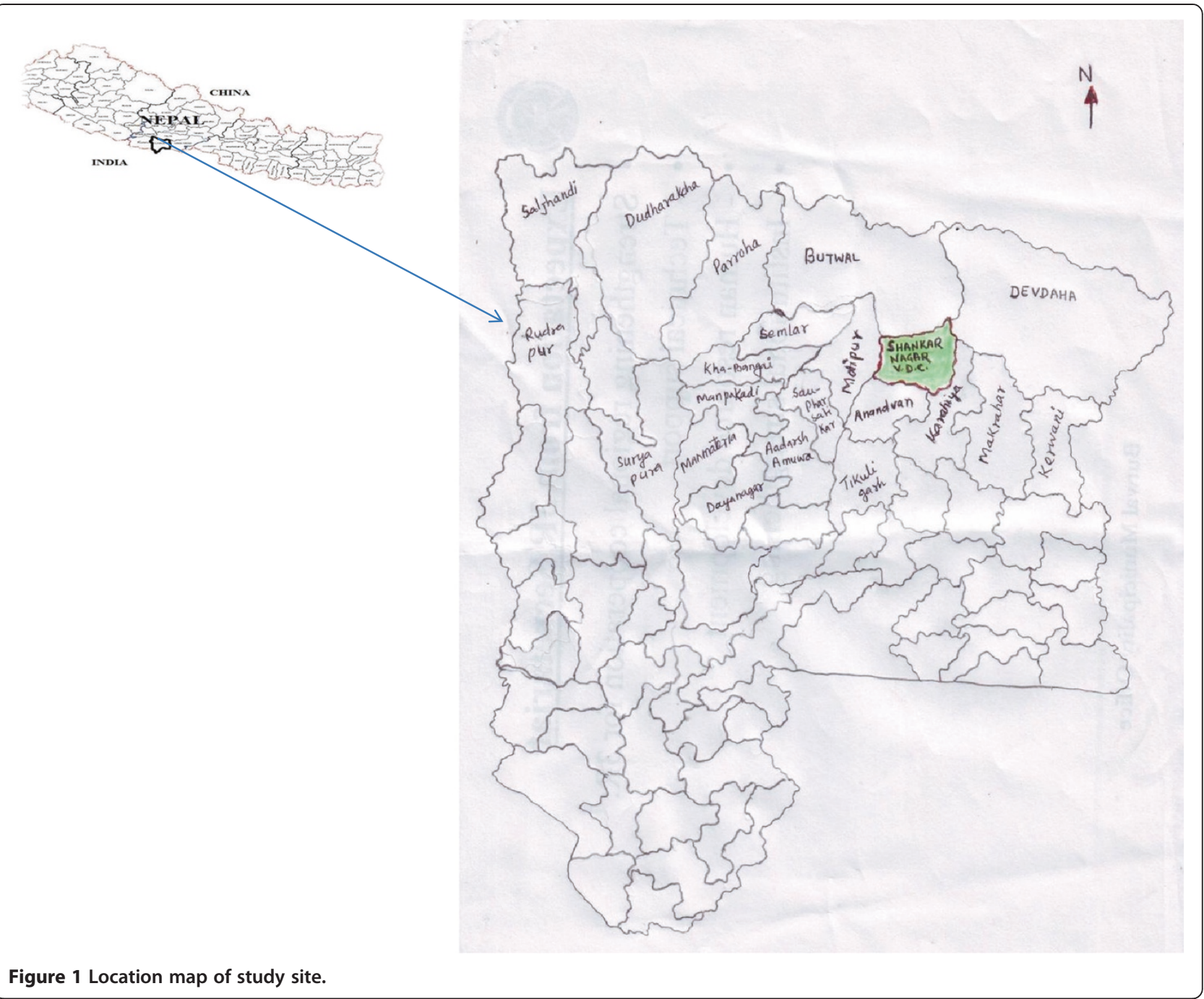

part of the country from the east to west along IndoNepal boarder and the adjacent valleys and plains between the Chure hilly regions. The Tharus are famous for their ability to survive in the moist Terai region which is deadly to outsiders due to malaria. They are farmer by occupation and cultivate rice, mustard, corn and lentils but also collect forest products such as wild fruits, vegetables, medicinal plants and material to build their houses, hunt wild animals and fishes [33].

\section{Materials and methods}

\section{Field works and collection of data}

Field studies were conducted from March 2010 to May 2011. Methods of Martin [34] were followed for the collection of data and voucher specimen during the field study. First of all local administrative officers were consulted with the explanation of aims and objectives of the research for the identification of resource persons (informants). They give advice regarding the people who would be the best sources of information. Researchers meat these peoples and explain the research theme. These informants often suggested other potential informants. In order to insure a sample that includes representatives of whole community, we attempted to interview peoples from variety of age groups, sex, socioeconomic and ethnic community (for detail information about gender, age, ethnicity, and occupation of informants please see Table 1). The criteria for the selection of informants for the interview were their reputation in the society regarding their knowledge about herbal medicines and traditional healthcare system. Total 55 informants were identified from Shankar Nagar VDC and surrounding areas. They are reputed knowledgeable persons of the society and the collected data from these informants represent the whole community, because they are knowledgeable healers, villagers, senior citizens, teachers, social workers etc. Prior to survey, a questionnaire was designed and pre-tested with five informants 
Table 1 Detail of informants interviewed in terai forest of western Nepal

\begin{tabular}{|c|c|c|c|c|c|}
\hline $\mathrm{SN}$ & Name & Age $(\mathrm{Y})$ & Sex & Address & Occupation \\
\hline 1 & Durga Pd Shrestha & 69 & M & Butwal-12 Kalikanagar, Rupandehi & Senior citizen, knowledgeable person \\
\hline 2 & Mohan Lal Tharu & 26 & M & Motipur-5, Rupandehi & Plant collector \\
\hline 3 & Babu Ram Rana & 65 & M & Paschim Amuwa-5, Rupandehi & Local healer, farmer \\
\hline 4 & Laxman Aryal & 43 & M & Shankar Nagar-4, Rupandehi & Secretary, VDC, Shankar Nagar \\
\hline 5 & Khadanand Poudyal & 58 & M & Shankar Nagar-4, Rupandehi. & Shopkeeper \\
\hline 6 & Bhagirathi Tharu & 63 & M & Motipur-5, Rupandehi & Local healer (vaidya), farmer \\
\hline 7 & Indra Bdr. Bhujel & 39 & M & Paschim Amuwa-4, Rupandehi & Fodder collector, farmer \\
\hline 8 & Krishna Bdr. Rana & 64 & M & Ram Nagar Butwal-12, Rupandehi & Plant collector, farmer \\
\hline 9 & Harka Bdr. Rasaily & 47 & M & Semlar-7, Rupandehi & Local healer, farmer \\
\hline 10 & Yam Bdr. K. C. & 52 & M & Manpakadi-8, Rupandehi & Fodder expert, healer, farmer \\
\hline 11 & Indrawati Tharuni & 58 & $\mathrm{~F}$ & Sou. Pharsatikat-4, Rupandehi & Local healer, farmer \\
\hline 12 & Khadak Thapa & 44 & M & Shankar Nagar-9, Rupandehi & Plant collector, farmer \\
\hline 13 & Kishuni Tharuni & 49 & $\mathrm{~F}$ & Dudhraksh- 5, Rupandehi & Plant collector, local healer \\
\hline 14 & Yam Bdr Thapa Magar & 54 & M & Saljhandi-4, Rupandehi & Local healer, plant collector \\
\hline 15 & Top Naarayan Ghimire & 56 & M & Motipur-4, Rupandehi & Secretary of chartapa irrigation, local healer, farmer \\
\hline 16 & Ram Kumari Chai & 58 & $\mathrm{~F}$ & Sikthan-4, Rupandehi & Active women farmer \\
\hline 17 & Sher Bdr. Budhathoki & 73 & M & Kalika Nagar, Butwal-12, Rupandehi & Senior citizen, farmer \\
\hline 18 & Gopal Pd. Neupane & 69 & M & Shankar Nagar-1 Chaparhatti, Rupandehi & Local knowledgeable healer, farmer \\
\hline 19 & Khushi Lal Tharu & 58 & M & Motipur-5, Rupandehi & Plant collector, local healer (vaidya) \\
\hline 20 & Narjeet Tharu & 53 & M & Motipur-7 Rupandehi & Local healer, farmer \\
\hline 21 & Rajendra Lodh & 47 & M & Shankar Nagar-3, Rupandehi & Local healer, farmer \\
\hline 22 & Nar Bdr. G. M. & 52 & M & Gopalpur, Kha Bangai-4 Rupandehi & Farmer, local healer \\
\hline 23 & Sun Bdr. Gaha & 67 & M & Koldanda-1 Lagad, Palpa & Local Healer, head of Lagad Village, Palpa. \\
\hline 24 & Luk Bdr. Gaha & 58 & M & Koldanda-1 Lagad, Palpa & Plant collector and exporter. \\
\hline 25 & Punam Kunwar & 33 & $\mathrm{~F}$ & Butwal-12, Rupandehi & Secretary, Butwal -12 , service. \\
\hline 26 & Laxmi Narayan Chaudhary & 48 & M & Parroha-2 Rupandehi & Farmer, local healer \\
\hline 27 & Nar Bdr. Rana & 49 & M & Shital Nagar, Devdaha, Rupandehi & School teacher, farmer \\
\hline 28 & Ram Ratan Gupta & 58 & M & Siloutiya 5 Marchwar, Rupandehi & Head master, secondary school, odwalia \\
\hline 29 & Ganga Kharel & 47 & $\mathrm{~F}$ & Shankar Nagar-3 Rupandehi & Health assistant \\
\hline 30 & Bhim Pd Neupane & 66 & M & Motipur- 4 Rupandehi & Senior citizen, Ex VDC Chairman \\
\hline 31 & Yam Bdr G.M. & 43 & M & Makrahar-6 Rupandehi & Local healer \\
\hline 32 & Hare Ram Yadav & 55 & M & Motipur-2, Rupandehi & Mukhiya, Panchmauja, Chartapa irrigation, farmer \\
\hline 33 & Mrs. Janaki Aryal & 48 & $\mathrm{~F}$ & Motipur-7, Rupandehi & Social worker, farmer \\
\hline 34 & Salik Ram Aryal & 64 & M & Sou-pharsatikar-1, Rupandehi & Senior citizen, Ex VDC chairman \\
\hline 35 & Mrs. Rita Wasti & 52 & $\mathrm{~F}$ & Motipur-7, Rupandehi & Farmer and knowledgeable woman \\
\hline 36 & Krishna Chand Chaudhary & 59 & M & Kha-Bangai-4, Rupandehi & Local healer, farmer \\
\hline 37 & Durga Khanal & 58 & M & Semlar-3, Rupandehi & Secretary of Semlar VDC \\
\hline 38 & Chhabi Lal Neupane & 64 & M & Motipur-7, Rupandehi & Mukhiya, farmer \\
\hline 39 & Chautare Pd. Tharu & 72 & M & Motipur-7, Rupandehi & Local healer,farmer, member of 11 mauja irrigation, chartapa \\
\hline 40 & Krishna Kumar Thapa & 38 & M & Motipur-2, Rupandehi & Plant collector \\
\hline 41 & Om Prakash Aryal & 38 & M & Motipur-9, Rupandehi & Farmer, plant collector \\
\hline 42 & Ishwar Raj Lamsal & 58 & M & Butwal -10, Deepnagar, Rupandehi & Knowledgeable person \\
\hline 43 & Om Prakash Chaudhary & 52 & M & Butwal -13, Devinagar, Rupandehi. & Knowledgeable local healer \& Farmer \\
\hline 44 & Sohan Lal Chaudhary & 48 & M & Karhiya-2, Rupandehi & Plant collector \& Farmer \\
\hline
\end{tabular}




\section{Table 1 Detail of informants interviewed in terai forest of western Nepal (Continued)}

\begin{tabular}{llllll}
\hline 45 & Ram Prasad Tiwari & 62 & M & Tikuligadh-3, Rupandehi & Local Plant collector \\
46 & Krishna Mohan Kohar & 42 & M & Basantpur-2 Rupandehi & Knowledgeable person, teacher \\
47 & Rammu Prasad Chaudhary & 65 & M & Piparanhwa, Baguali-3, Rupandehi & Knowledgeable person \\
48 & Kamal Narayan Chaudhary & 55 & M & Anandban VDC-4, Rupandehi & Knowledgeable person \\
49 & Bhiku Prasad Chaudhary & 46 & M & Kalika Nagar, Butwal-12, Rupandehi & Knowledgeable person \\
50 & Dil Bahadur Mukhiya & 42 & M & Kalika Nagar Butwal- 13, Rupandehi & Plant collector \\
51 & Mandali Tharu & 56 & M & Kha- Bangai-6, Rupandehi. & Local healer, Gurau \\
52 & Tameshwar Tharu & 52 & M & Gopalpur, Kha- Bangai-2, Rupandehi & Local healer, plant collector \\
53 & Harihar Tharu & 48 & M & Bhujauli, Kha- Bangai-7, Rupandehi & Local healer, plant collector \\
54 & Tulshi Prasad Chaudhary & 53 & M & Kha-Bangai-6, Rupandehi & Knowledgeable person \\
55 & Khadag Bahadur Mahat & 51 & M & Kalika Nagar Butwal-12, Rupandehi & Knowledgeable person, social worker \\
\hline
\end{tabular}

$\mathrm{S} \mathrm{N}=$ serial number; $\mathrm{Y}=$ years; $\mathrm{M}=$ male; $\mathrm{F}=$ female.

to find out its suitability for present study and modified according to response of informants. The revised questionnaire was used for gathering data about medicinal plants of the study area. Pre informed consent was obtained from the resource persons before interview. Field survey was conducted taking traditional healers as a guide and voucher specimens of cited medicinal plants were collected and their local identity was re-confirmed by other informants. During data collection three visits (in each visit author stay for four days in study area) was conducted and information's were collected. The information obtained was cross checked with the other informants. The local names, habit, wild/cultivated, availability of medicinal plants, need of conservation and efforts made by inhabitants and traditional medicinal uses of plants were carefully recorded. Finally, group discussion ware made with the healers and local people to know their perception about the use of traditional folk medicines, awareness about the conservation of phytodiversity and indigenous knowledge.

\section{Processing of voucher specimens for herbarium preparation and identification}

The voucher specimens were brought to the laboratory and processed for herbarium specimen preparation [3436 and identified with the help of available floras and other pertinent literatures $[8,11,23,37-42]$ and submitted in department of Botany, Butwal Multiple Campus, Tribhuvan University, Nepal for future references. The botanical identities of collected specimens were confirmed by Dr. M. P. Panthi, and Mr. B. R. Nepali, Taxonomist, Tribhuvan University, Kathmandu, Nepal. Plant names were checked according to International Plant Name Index [43].

\section{Statistical analysis}

The data were spreads on Excel sheet to summaries and to identify various proportions like plant families, habit, availability of medicinal plants, plant parts used as medicine, methods of use, frequency of citation and popularly used medicinal plants in the study area. Frequency of citation was calculated by following formula-

$$
\begin{aligned}
& \text { Frequency of citation }(\%)=\frac{\text { who cited the species }}{\text { Total number of }} \times 100 \\
& \text { informats interviewed }
\end{aligned}
$$

Factor of informants consensus $\left(\mathrm{F}_{\mathrm{IC}}\right)$ for different ailment categories was calculated for testing homogeneity on the informant's knowledge followed by the method provided by Trotter and Logan and Heinrich et al. as under $[44,45]$.

$$
F_{I C}=\frac{N_{U R}-N_{T A X A}}{\left(N_{U R}-1\right)}
$$

Where $\mathrm{N}_{\mathrm{UR}}$ = number of use report in a particular illness category and $\mathrm{N}_{\mathrm{TAXA}}=$ number of taxa used to treat that particular category by informants.

\section{Result and discussion}

Medicinal plants and their uses

Altogether 66 medicinal plants belonging to 37 families and 60 genera were documented from the study area (Table 2). The documented medicinal plants and their ethnomedicinal uses along with common name have been summarized in Table 2. These plant species are used for the treatment and prevention of many ailments and diseases grouped under 11 ailment categories (Table 3). The common sickness for the tribal in the study area are cold, cough, bronchitis, diarrhoea, dysentery, gastritis, headache, backache, cuts, wounds etc. Symptoms of the diseases given by the tribes in local language with their bio-medical terms are given in Table 4. Exact doses and duration of treatment are considered as intellectual property of informants, so as per their request this information is not included in the present paper. Curcuma longa (84\%), Azadirachta indica 
Table 2 Ethnomedicinal plants of Terai forest in western Nepal and their traditional therapeutic uses

\begin{tabular}{|c|c|c|c|}
\hline $\begin{array}{l}\text { Botanical name, family, } \\
\text { voucher no. }\end{array}$ & $F$ & $\begin{array}{l}\text { Local name/habit/ } \\
\text { availability }\end{array}$ & Parts used \\
\hline $\begin{array}{l}\text { Acacia catechu (L.f.) Willd., } \\
\text { Fabaceae, AGS-45 }\end{array}$ & 22 & $\begin{array}{l}\text { Khayar (N/M)/Tree/Wild/ } \\
\text { Rare }\end{array}$ & Bark, wood \\
\hline $\begin{array}{l}\text { Acalypha indica L., } \\
\text { Euphorbiaceae, AGS-66 }\end{array}$ & 15 & $\begin{array}{l}\text { Mukta barshi jhar (N),/ } \\
\text { Herb/Wild/Easily }\end{array}$ & Entire plant \\
\hline $\begin{array}{l}\text { Acorus calamus L. } \\
\text { Acoraceae, AGS-71 }\end{array}$ & 27 & $\begin{array}{l}\text { Bojho (N)/Katara (Th)/Herb/ } \\
\text { Wild }\end{array}$ & Root \\
\hline $\begin{array}{l}\text { Achyranthes aspera L. } \\
\text { Amaranthaceae, AGS- } 33\end{array}$ & 33 & $\begin{array}{l}\text { Ulta chirchiri (Th)/Datiwan } \\
\text { (N)/Herb/Wild/Easily }\end{array}$ & Entire plant \\
\hline
\end{tabular}

Amaranthaceae, AGS- 33

Aegle marmelos (L.) Correa ex Roxb., Rutaceae,

AGS- 25

Ageratum conyzoides L.

Asteraceae, AGS-49

Aloe vera (L.) Burm.f.

Aloaceae, AGS- 38

Amaranthus spinosus L.

Amaranthaceae, AGS-15

Argemone mexicana $\mathrm{L}$.

Papaveraceae, AGS-11

Artemisia indica Willd.

Asteraceae, AGS-52

Asparagus racemosus Willd.,

Liliaceae, AGS-28

Azadirachta indica A. Juss., Meliaceae, AGS- 8

Bacopa monnieri (L.)

Pennel, Scorphulariaceae,

AGS-21

Bauhinia variegata $\mathrm{L}$

Fabaceae, AGS-68

Bombax ceiba L.

Bombacaceae, AGS- 35

Calotropis gigantea (L.) W.T.

Aiton, Asclepiadaceae,

AGS-12

Carica papaya L. Caricaceae

Centella asiatica (L.) Urb.

Apiaceae, AGS- 36

Chenopodium album L.

Chenopodiaceae, AGS-9

Citrus limon (L.) Burm. f.

Rutaceae,

Colocasia esculenta (L.)

Schott, Araceae, AGS-19

Coriandrum sativum L.

Apiaceae
20 Bel (N/Th) /Tree/Cultivated Fruit pulp, leaf and root

38 Gandhe jhar (N)/Gandhaula Leaf (Th)/Herb/Wild/Easily

35 Ghiu Kumari (N)/Ghrit Kumari (Th) Herb/ Cultivated

38 Ban lunde (N)/Kande Lundo (M)/Herb/Wild, easily

36 Bharbhanda (Th)/Herb/ Wild, easily

18 Tite pati (N)/Pati (Th)/Herb/ Tender shoot and wild or cultivated leaves

31 Kurilo(N)/Santawar (Th)/ Tuberous root Herb/cultivated

76 Neem (N/M/Th)/Tree/Wild and cultivated

16 Jal nim, Brahami(N)/Khole Sag (M/Th)/Herb/Wild/ Easily in northern parts, rare in southern parts

42 Koiralo (N)/Koilar (Th)/Tree/ Bark and flower juice cultivated

22 Simal (N)/Semar (Th)/Tree/ Root Wild/Rare

15 Aank (N)/Madar (Th)/ Shrub/Wild/Easily

Root, Milky latex and flower/Shrub

18 Mewa (N)/Papita, Larmewa Latex and fruit (Th)/Shrub/cultivated

29 Ghod Tapre (N)/Ghortapya, Entire plant Bhatbhate(Th)/Herb/wild

27 Bethe (N)/Bethuwa (Th)/ Tender shoot and Herb/Wild/Easily

flower

49 Kagati (N)/Nibuwa (Th)/ Leaves and fruit Shrub/Cultivated

20 Pindalu, Karkalo (N)/Gabha, Corm and tender Ghuiya (Th)/Herb/cultivated aerial parts

18 Dhaniya (N/M/Th)/Herb/ Leaf and seeds cultivated
Usages

*Bark powder is applied on tooth ache. *Wood decoction is given orally in intestinal pain. Bark paste is applied in skin diseases.

*Plant decoction is given orally in toothache and earache. *Leaf paste is applied on burns. *Fresh leaf juice is applied on rheumatoid arthritis.

Juice of root is given orally in stomach disorders, bronchitis, fever and its small piece chewed to clear the throat and open the voice.

Decoction of plant is given as diuretic. Root juice is applied to treat toothache. *Root juice is given orally asthma. Stem is used as toothbrush in tooth problems.

Fruit juice is given orally in Diarrhoea and dysentery. Leaves are given orally in stomach disorders. * Root juice is given orally in fever and vomiting.

Leaf juice is given to cure bleeding from cuts and wounds. Plant paste is applied to cure muddy wounds between toes during rainy season.

* Leaf pulp is given orally in lung disease and stomach disorders. Leaf pulp is applied on skin burns.

Root decoction is given as diuretic. Tender shoot is given to cure leucorrhoea, flatulence, and colic pain.

Milky juice of the plant is applied on tumors and skin diseases. Root paste is applied on skin diseases and flatulence.

* Leaf juice is given orally in bronchitis. Leaf paste is applied in skin diseases. Dried tender shoot powder is given orally in fever.

Dried root powder is given orally with hot water to cure urinary troubles. Root decoction is given orally after delivery as tonic. Tuberous root powder is given orally to increase lactation.

Decoction of fresh leaves is used to wash skin to treat scabies. Young stem is used as tooth brush in tooth problems. Fresh leaves are given orally for the purification of blood and for control of sugar level. Tender twigs paste is applied on wounds for early healing.

Plant juice is given orally as diuretic, cardiac tonic and memory enhancer. Plant juice is given as hair tonic especially in thinning and falling hairs.

*Bark decoction and flower juice are given in Diarrhoea, dysentery, indigestion and body ache. *Bark decoction is given to cure tumors.

Root decoction is given as tonic, anti-dysenteric and in urinary troubles. *Bark decoction is given orally in bronchial diseases.

Root paste applied on boils, pimples, and skin disease. Milky latex is applied on muscular pain, cut, wounds, boils, and ringworm. *Flower powder is given orally in cough, cold, and bronchitis.

*Milky latex is given in toothache and dysentery.

Plant decoction is given orally as diuretic, tonic, blood purifier and in skin diseases, leprosy, and mental disorder. Leaf juice is given orally in indigestion.

Tender shoot and flower juice is given orally to kill and expel the round worm and in constipation.

*Leaves are chewed to expel intestinal worms. *Rind paste and fruit juice is applied in pimples and dandruff.

*Petioles used as green vegetables in liver problems. * Corm paste is applied over cuts/wounds to stop bleeding.

*Leaf paste is applied on allergic inflammation. *Green leaves are used in the preparation of soft drink along with sugar and given orally inx stomachache. 
Table 2 Ethnomedicinal plants of Terai forest in western Nepal and their traditional therapeutic uses (Continued)

\begin{tabular}{ll}
\hline $\begin{array}{l}\text { Curcuma longa L., } \\
\text { Zingiberaceae }\end{array}$ & $84 \begin{array}{l}\text { Besar (N)/Hardi (Th)/Herb/ } \\
\text { Cultivated }\end{array}$
\end{tabular}

Zingiberaceae

Curcuma amada Roxb. Zingiberaceae, AGS-34

Cuscuta reflexa Roxb.

Convolvulaceae, AGS- 65

Cymbopogon citratis (DC. ex. Nees) Stapf, Poaceae, AGS-50

\author{
Cyperus rotundus $\mathrm{L}$. \\ Cyperaceae, AGS-48 \\ Cynodon dactylon (L.) Pers. \\ Poaceae, AGS-5
}

Dalbergia sissoo Roxb.,

Fabaceae, AGS-40

Datura metel L. Solanaceae AGS-3

Dendrocalamus hamiltonii Nees \& Arn. ex Munro,

Poaceae, AGS-67

Dioscorea pentaphylla L., Dioscoreaceae, AGS-32

Drymaria diandra Blume Caryophyllaceae, AGS-64

Eclipta prostrata L.

Asteraceae, AGS-6

Euphorbia hirta L. Euphorbiaceae, AGS-22

Ficus benghalensis $\mathrm{L}$ Moraceae, AGS-30

Gloriosa superba L., Liliaceae, AGS-31

Ipomoea aquatica Forssk., Convolvulaceae, AGS-16

Ipomoea batatas (L.) Lam., Convolvulaceae

Ipomoea carnea Jacq. ssp. fistulosa (Mart. ex Choisy) D. Austin, Convolvulaceae, AGS-23

\section{Justicia adhatoda L.,} Acanthaceae, AGS-14

Lagenaria siceraria (Molina) Standl., Cucurbitaceae

Lepidium sativum L., Brassicaceae, AGS-63, (Th) /Herb/ Cultivated Parasitic climber/wild

16 Pire ghans (N)/Kagati Leaves ghans(Th)/Herb/Cultivated

20 Mothe (N)/Bhada (Th)/ Tuber Herb/Wild/Easily Wild/Easily cultivated and wild Kalo Dhatu
Wild/Easily

27 Tama Bans (N/M)/Shrub/ Wild/Easily

18 Bhyakur (N)/Ban Tarul (Th)/ Rhizome Climber/Wild (Th)/Herb/Wild/Rare Bhangaraila (Th)/Herb/ Wild/Easily Jharra (Th) Herb/Wild/Easily

$29 \operatorname{Bar}(\mathrm{N}) /$ Bargad (Th)/Tree/ Wild/Easily Tree

38 Karihari, Kewari (N)/ Climber/Wild/Easy Sag, Karmaiya Sag (Th)/ Herb/Wild/Easily

16 Shakarkand (N)/Herb/ Cultivated leaf juice Shrub/Wild/Easily

42 Asuro (N)/Ross (Th)/Shrub/ Leaf Wild/Easily

18 Lauka (N)/Climber/ Cultivated

33 Chamsur (N/Th)/Herb/ Cultivated and wild
31 Aama haldi (N)/Amaadi Rhizome/Herb

53 Aakashbeli (N)/Baora (Th)/ Entire plant

27 Dubo (N)/Dub (Th)/Herb/ Entire plant

18 Sisau (N)/Sisava (Th)/Tree/ Bark and leaf juice

Bark and leaf juice

Leaf, stem and seed

Tender shoot and stem node

16 Abijalo (N), Sirbire Jhar Entire plant

22 Bhringi jhar, Bhringraaj (N)/ Entire plant

33 Dudhe Jhar (N)//Doodhe Entire plant

Bark and milky latex/ Bark infusion is given orally in diabetes. *Milky latex is applied on

40 Kerunga Sag (N)/Kermua Tender shoot

Tuberous root and

16 Behaya (Th),Besharam (N)/ Latex of leaf and tender shoot

Rhizome decoction is given as stimulant, tonic, and blood purifier. Rhizome paste is externally applied on strains, wounds, and injuries. Fresh rhizome juice is given as anthelmintic. Rhizome powder is given orally with luck warm water in jaundice and liver disorders.

*Rhizome powder is given as digestive to clean throat and tongue. *Rhizome paste is externally applied on strains, rheumatism, and inflammation.

* Juice of the plant is given orally to treat fever. Plant paste is applied externally to treat headache, stomachache and rheumatism. Plant paste is applied on fractures.

Leaves are used to make tea and given orally in cough, cold, headache, and fever.

Tuber infusion, with sugar/salt is given orally in dysentery, Diarrhoea, and indigestion and as anti inflammatory agent.

Plant paste is applied on cuts and wounds. *Root infusion along with sugar is given orally in bleeding piles and indigestion. *Plant juice used as eardrop in earache.

Bark and leaf juice are given orally in Diarrhoea, dysentery and as anthelmintic. It is applied externally on cut and wounds. *Leaf decoction is given orally in gonorrhea.

Leaves juice is given orally in epilepsy. ${ }^{*}$ Dried stem and leaves are smoked in asthma. *Seeds are boiled in mustard oil and massaged on joint pains.

*Stem node paste is applied on boils. *Tender shoots (Tama) is consumed as vegetable as aphrodisiac.

*Boiled Rhizome is given orally in abdominal pain.

Root juice is inhaled to treat sinusitis.

Plant paste is applied on cut, wounds, skin diseases, and pimples.

Plant juice is applied on cuts and wounds. Leaf juice is given orally in diarrhoea.

muscular pain

*Rhizome paste is applied externally on ringworm and other skin diseases.

*Tender shoot is used as vegetable in gastric trouble and general debility.

*Leaf juice is given orally in diabetes.

* Latex of leaf and tender shoot are applied as antiseptic on wounds between toes in rainy seasons.

Warm decoction of the leaves is given to treat asthma. Juice of fresh leaves along with honey is given orally as expectorant. Juice of leaf is inhaled in bleeding nose (sinusitis). Dried powder of entire plant parts is given in bronchitis and cough.

Leaf, fruit and seed *Leaf decoction with sugar is given in jaundice. Fruit juice is given in diarrhoea and, dysentery *Seeds are given as mental tonic.

Entire plant Seed paste is applied on rheumatism. *Fresh leaves are given orally in liver problems. 


\section{Table 2 Ethnomedicinal plants of Terai forest in western Nepal and their traditional therapeutic uses (Continued)}

\begin{tabular}{|c|c|c|}
\hline $\begin{array}{l}\text { Linum usitatissimum L., } \\
\text { Linaceae, }\end{array}$ & $\begin{array}{l}18 \text { Tishi (Th), Alasa (N)/Herb/ } \\
\text { Cultivated }\end{array}$ & Seed, and seed oil \\
\hline $\begin{array}{l}\text { Malva parviflora L., } \\
\text { Malvaceae, AGS-31 }\end{array}$ & $\begin{array}{l}25 \text { Laphe sag (N)/Bariyara } \\
\text { (Th)/Herb/Wild/Easily }\end{array}$ & $\begin{array}{l}\text { Tender shoots \& } \\
\text { Seeds }\end{array}$ \\
\hline
\end{tabular}

Melia azadirachta L., Meliaceae, AGS- 41

Mentha spicata $L$., Lamiaceae, AGS-18

Mimosa pudica L., Fabaceae, AGS-60

Mucuna pruriens (L.) DC. Fabaceae, AGS-53

Musa paradisiaca L., Musaceae

Ocimum tenuiflorum L., Lamiaceae, AGS-24

Phragmites vallatoria (L.) Veldkamp, Poaceae, AGS64,

Phyllanthus emblica L., Euphorbiaceae, AGS-17

Polygonum barbatum L., Polygonaceae, AGS-26,

Rauvolfia serpentina Benth. ex Kurz Apocynaceae, AGS37

Rumex nepalensis Spreng, Polygonaceae, AGS-61

Ricinus communis L., Euphorbiaceae, AGS-4

Shorea robusta C.F. Gaertn., 20 Sal (N)/Sakhuwa (Th)/Tree/ Dipterocarpaceae, AGS19

Solanum nigrum $L$., Solanaceae, AGS-2

Syzygium cumini (L.) Skeels, Myrtaceae, AGS-29

Terminalia bellirica (Gaertn.) Roxb., Combretaceae, AGS 39

Terminalia chebula Retz., Combretaceae, AGS-64

Tribulus terrestris L. Zygophyllaceae, AGS-47
60 Bakaino (N)/Bakain (Th)/ Entire plant Tree/Wild/Easy

38 Pudina (N)/Patina (Th)/ Entire plant Herb/Cultivated

20 Boohari Jhar (N)/Lajjalu Entire plant Jhar (Th)/herb/Wild/Easily

27 Kauso (N)/Kewanch (Th) Climber/Wild/Easily

18 Kera (N/M/Th)/Shrub/ Cultivated

47 Krishna Tulsi (N)/Kalo Tulsi (M)/Tilsi (Th)/Herb/Wild/ Easily Wild/Easily

45 Amala (N)/Aura (Th)/Tree/ Bark juice and fruit. cultivated,

13 Pire Jhar (N)/Bisnair (Th)/ Entire plant Herb/Wild/Easily

47 Sarpagandha (N)/Chand maruwa (M)/Dhaldhaliya (Th)/Shrub/Rare in southern parts and Cultivated in northern parts

24 Halhale Sag (N/Th)/Ban Palungo (M)/Herb/Wild/ Easily

31 Ander (N)/Redi, Yamyam (Th)/Shrub/Wild/Easily seeds

Entire plants/Herb

Root/Herb

Leaf \& root

Entire plant

Root and seed
21 Narkat (N//M/Th)/Herb/

Roots, fruits and seed

36 Kali gedi (N)/Kamai (Th)/ Entire plant Herb/Wild/Easily

40 Phader (N)/Jamuno (M)/ cultivated

36 Barro (N)/Baheda (Th)/Tree/ Stem bark and fruit. cultivated cultivated

16 Gokharu, Gaikhure Jhar (N)/ Entire plant Herb/Wild/Rare
Leaf, flower and fruit Unripe fruits are roasted and given orally in Diarrhoea and dysentery. Extract of flowers, fruits and leaves are applied on skin burns. Stem extract reduces sugar level in blood.

Decoction of, plant is given in fever, cough, cold, headache, nausea, Diarrhoea, dysentery and skin diseases. Leaf juice is used as ear drops in earache. Leaf powder with honey is given orally in diabetics.

${ }^{*}$ Root decoction is given orally as refrigerant, diuretic and diaphoretic.

Bark juice is given orally in dysentery, constipation, and body ache Fruits decoction is given orally in shore throat and as tonic.

Poultice is applied externally on swelling parts of the body. ${ }^{*}$ Root is given orally as astringent and cooling agent. Leaf decoction is applied externally to wash ulcers.

Dried root powder is given orally to reduce high blood pressure. Root infusion is given orally in intestinal disorders. *Leaf juice is used as remedy for the removal of opacities of cornea. Root paste is applied on cuts, wounds, or boils.

Seeds infusion is used in mouth disorders. Root paste applied externally on joint pains and wounds. Fresh leaf extract and sap is applied on cuts, wounds, and swellings.

Root juice is given orally in diarrhoea, dysentery, and skin diseases. * Seed oil is applied as massage for babies and also applied on sole to relief from burning sensation. Seed oil is given orally in constipation and rheumatic pain.

Root, Bark, resin and Decoction is given orally in Diarrhoea and bloody dysentery. *Bark juice Jam (Th)/Tree/Wild and

36 Harro (N)/Harad (Th)/Tree/ Stem bark and fruit. is used as eardrop in earache.

* Unripe fruits paste is applied on ringworm. Ripe fruits are given orally in constipation. Plant paste is applied externally in headaches and joint pain. Plant juice is given orally in liver enlargement, dysentery and fever

Bark juice is given orally in Diarrhoea, dysentery, cut and wounds. Fruits are given orally in indigestion and constipation. Bark, Leaf and seed powder is given orally to reduce sugar level in blood.

Bark juice is applied externally in cut, wounds, and skin diseases. Fruits powder is given orally in cough, cold, respiratory problems, fever, and indigestion.

*Bark is chewed in urinary problems. Fruits are given orally in cough, cold, respiratory troubles, fever, and indigestion and stomach problems.

*Decoction is given orally in urinogenital tract infection. 
Table 2 Ethnomedicinal plants of Terai forest in western Nepal and their traditional therapeutic uses (Continued)

\begin{tabular}{|c|c|c|c|c|}
\hline $\begin{array}{l}\text { Vitex negundo L., Vitaceae, } \\
\text { AGS-69 }\end{array}$ & 38 & Simali (N)/Shrub/Wild/Easily & Leaf juice and bark & $\begin{array}{l}\text { Leaf juice is given orally in cough, cold, sinusitis, fever, stomach } \\
\text { problems, and rheumatic swellings. Bark paste is applied on boils. }\end{array}$ \\
\hline $\begin{array}{l}\text { Zingiber officinale Roscoe, } \\
\text { Zingiberaceae }\end{array}$ & 73 & $\begin{array}{l}\text { Aduwa (N)/Suntho (Th)/ } \\
\text { Herb/cultivated }\end{array}$ & Rhizome & $\begin{array}{l}\text { Rhizome juice is given in cough, cold, fever, indigestion, and } \\
\text { constipation. Rhizome is chewed in bronchial infections. }\end{array}$ \\
\hline $\begin{array}{l}\text { Ziziphus mauritiana Lam., } \\
\text { Rhamnaceae, AGS-43 }\end{array}$ & 51 & Bayer (N)/Tree/Wild/easily & Stem bark and fruit. & $\begin{array}{l}\text { The juice of bark is given orally to treat Diarrhoea and dysentery. Ripe } \\
\text { fruit are given orally in indigestion, constipation and other stomach } \\
\text { problems. }\end{array}$ \\
\hline
\end{tabular}

"Exact doses and duration of treatment are considered as intellectual property of informants, so as per their request this information is not included in the present paper. $\mathrm{F}=$ Frequency of citation; $\mathrm{N}=$ Nepali; $\mathrm{M}=$ Magar; $\mathrm{Th}=$ Tharu. ${ }^{*}=$ New reports.

(76\%) are the most frequently and popularly used medicinal plant species in the study area.

\section{Growth forms, plant parts used, method of collection, processing and administration}

Out of 66 medicinal plants recorded from study area, highest number of plants belongs to herb (53\%) followed by tree, shrubs and climber (Figure 2). Higher uses of herbs for medicinal purposes may be due to easy availability and high effectiveness in the treatment of ailments in comparison to other growth forms. Almost every plant parts are used for the medication either singly or in combination with other plants. Entire plant is used in the majority of cases followed by leaf, root and bark (Figure 3). Plant parts used as medicine is collected by healer themselves from natural resources. Generally fresh parts are collected for use from nature. Various plant parts are collected in different seasons at different stage of maturity and are dried in shade and stored in dry places away from direct sunlight for their use during off season/unavailability. As far as mode of use and administrations are concerned majority of the plants are used in form of juice, followed by decoction (Figure 4). Majority of the medicinal formulations are administrated orally in ailment categories other than dermatological. In dermatological problems plants are administrated topically as well as orally.

\section{Identification of new claims and reliability of reported claims}

Reported uses of various medicinal plants were compared with previously published ethnobotanical literatures in Nepal and adjoining areas of India [2-20,25,30] which identifies new medicinal uses of Acacia catechu, Acalypha

Table 3 Different ailments of study area grouped under different ailment categories with their biomedical terms and factor of informants' consensus

\begin{tabular}{|c|c|c|c|c|}
\hline Ailment categories & Biomedical terms & ${ }^{1} \mathrm{~N}_{\text {TAXA }}$ & ${ }^{2} \mathrm{~N}_{\mathrm{UR}}$ & ${ }^{3} \mathrm{~F}_{\mathrm{IC}}$ \\
\hline Gastro-intestinal disorders & $\begin{array}{l}\text { Constipation, Diarrhoea, Dysentery, Nausea, Indigestion, Vomiting, Stomach-ache, Gastric trouble, Loss } \\
\text { of appetite, Intestinal worms, colic pain, Flatulence, piles }\end{array}$ & 41 & 836 & 0.95 \\
\hline $\begin{array}{l}\text { Dermatological disorders } \\
\text { and cosmetics }\end{array}$ & $\begin{array}{l}\text { Cut, Wounds, Boils, Pimples, Skin rushes, Ringworm, Scabies, Leprosy, Skin burns, Skin blemishes, } \\
\text { Ecto-parasites, Skin diseases, Hair problems, Body Inflammation }\end{array}$ & 34 & 591 & 0.94 \\
\hline Respiratory diseases & Common cold, cough, asthma, Bronchitis, Chest pain, Lung disorders & 13 & 235 & 0.94 \\
\hline Fevers & Ordinary fever, diaphoretic Malaria, Typhoid, & 11 & 213 & 0.95 \\
\hline Ureno-genital problems & $\begin{array}{l}\text { Sexual debility, Infertility, Leucorrhoea, Gonorrhoea, Menstrual disorders, Frequent urination, Diuretic, } \\
\text { aphrodisiac }\end{array}$ & 14 & 190 & 0.93 \\
\hline Ear, Nose, Throat problems & Earache, Throat shore, Nose bleeding, Sinusitis & 12 & 205 & 0.94 \\
\hline Oral and dental disorders & Toothache, Mouth shore, & 8 & 141 & 0.95 \\
\hline Mental disorders & Mental tonic, memory tonic, Epilepsy & 4 & 44 & 0.93 \\
\hline $\begin{array}{l}\text { Skelto-muscular pain } \\
\text { and swelling }\end{array}$ & Body ache, muscular pain, Sprain, Strain, Rheumatism, Arthritis, Head ache, Joint pain, swelling & 16 & 245 & 0.93 \\
\hline Cardio-vascular disorder & Cardiac, blood pressure & 2 & 35 & 97 \\
\hline Other & Fracture, Tonic, Lactation, Easy delivery, Tumour, Diabetes, Cooling agent, stimulant and Eye problems & 20 & 414 & 0.95 \\
\hline Total & & $175^{4}$ & 3149 & 0.94 \\
\hline
\end{tabular}

${ }^{1} \mathrm{~N}_{\mathrm{UR}}=$ number of use report in a particular illness category and

${ }^{2} \mathrm{~N}_{\text {TAXA }}=$ number of taxa used to treat that particular category by informants.

${ }^{3} F_{I C}=$ Factor of informants consensus $=N_{U R}-N_{T A X A} /\left(N_{U R}-1\right)$, value of $F_{I C}$ ranges from 0 to 1 , high value shows agreement and low value shows disagreement among informants about the uses of taxa for the treatment of particular ailment category.

${ }^{4}$ Many plants are used for more than one ailment category. 
Table 4 Symptoms of the diseases given by the tribes in terai forest of western Nepal and their equivalent bio-medical terms

\begin{tabular}{|c|c|c|}
\hline $\begin{array}{l}\text { Ailment } \\
\text { categories }\end{array}$ & $\begin{array}{l}\text { Bio-medical } \\
\text { terms }\end{array}$ & Local terms \\
\hline \multirow{13}{*}{$\begin{array}{l}\text { Gastro-intestinal } \\
\text { disorders }\end{array}$} & Constipation & Kabjiyat hunu/Pet safa na hune \\
\hline & Diarrhoea & Pani jasto patlo dish hune \\
\hline & Dysentery & Aau pareko \\
\hline & Nausea & Kamjori hune wak-wak lagne \\
\hline & Indigestion & Khana apach hune \\
\hline & Vomiting & Banta/Ulti hune \\
\hline & Stomachache & Pet dukhne \\
\hline & Gastric trouble & Pet dhadiyeko \\
\hline & Loss of appetite & Khana ruchi na lagne/Bhok na lagne \\
\hline & Intestinal worms & Pet ma juka parnu \\
\hline & Colic pain & Tallo pet dukhne \\
\hline & Flatulence & Bayu gola le pet dukhne \\
\hline & Piles & Disha garne thaun ma mashu palaune \\
\hline \multirow{14}{*}{$\begin{array}{l}\text { Dermatological } \\
\text { disorders \& } \\
\text { cosmetics }\end{array}$} & Cuts & Katiyeko \\
\hline & Wounds & Ghau \\
\hline & Boils & Pilo, Khatira \\
\hline & Pimples & Dandiphore \\
\hline & Skin rushes & Chhala ma chilaune, rato dana hune \\
\hline & Ringworm & Daad hune, Chhala ko rog \\
\hline & Scabies & Luto, Kanaune rog, Khujali hune \\
\hline & Leprosy & Kushta rog \\
\hline & Skin burns & Ghamle chhala dadeko \\
\hline & Skin blemishes & Chhala ma hune rog \\
\hline & Ecto-parasites & Jumra parnu, juka lagnu \\
\hline & Skin diseases & Charma rog \\
\hline & Hair problems & Rauko rog, Kapal ko samsya \\
\hline & $\begin{array}{l}\text { Body } \\
\text { inflammation }\end{array}$ & Sarir sunnine ra polne \\
\hline \multirow{10}{*}{$\begin{array}{l}\text { Respiratory } \\
\text { diseases \& } \\
\text { Fever }\end{array}$} & Common cold & Chiso lageko \\
\hline & Cough & Khoki lageko \\
\hline & Asthma & Dam rog bhayeko, Swash phulne rog \\
\hline & Bronchitis & Ghanti ko rog \\
\hline & Chest pain & Chhati Dukheho \\
\hline & Lung disorders & Fokswo ko rog \\
\hline & Ordinary fever & Samanaya rog \\
\hline & Diaphoretic & Pasina bagaune rog \\
\hline & Malaria & Aulo Jwaro \\
\hline & Typhoid & Miyadi Jwaro \\
\hline \multirow{4}{*}{$\begin{array}{l}\text { Ureno-genital } \\
\text { disorders }\end{array}$} & Sexual debility & Saririk Kamjori \\
\hline & Infertility & Youn Durbalta \\
\hline & Leucorrhoea & Swet Pradar/Yoni bat seto pani bagne \\
\hline & Gonorrhoea & $\begin{array}{l}\text { Yoni bat ganaune pani jasto aaune/ } \\
\text { Estree haru ma youn rog }\end{array}$ \\
\hline
\end{tabular}

Table 4 Symptoms of the diseases given by the tribes in terai forest of western Nepal and their equivalent bio-medical terms (Continued)

\begin{tabular}{|c|c|c|}
\hline & $\begin{array}{l}\text { Menstrual } \\
\text { disorders }\end{array}$ & $\begin{array}{l}\text { Nachune huda ko rog/Mahinwari } \\
\text { huda lagne rog }\end{array}$ \\
\hline & $\begin{array}{l}\text { Frequent } \\
\text { urination }\end{array}$ & Pishab aayee rakhne \\
\hline & Diuretic & Pishab kholne \\
\hline & Aphrodisiac & Youn bardhak/Youn ko tagat \\
\hline \multirow{4}{*}{$\begin{array}{l}\text { Ear, Nose, } \\
\text { Throat } \\
\text { problems }\end{array}$} & Earache & Kan dukhne \\
\hline & Throat sore & Ghanti baseko \\
\hline & Nose bleeding & Nak bat ragat bagne \\
\hline & Sinusitis & Pinas bhayeko \\
\hline \multirow{2}{*}{$\begin{array}{l}\text { Oral \& Dental } \\
\text { disorders }\end{array}$} & Toothache & Dant Dukheko \\
\hline & Mouth sore & Mukhma ghau, dana hune \\
\hline \multirow{3}{*}{$\begin{array}{l}\text { Mental } \\
\text { disorders }\end{array}$} & Mental tonic & Buddhi badhaune aushadhi \\
\hline & Memory tonic & Smaranshakti badhaune aushadhi \\
\hline & Epilepsy & Chhare rog/Mirgi rog \\
\hline \multirow{9}{*}{$\begin{array}{l}\text { Skeleto- } \\
\text { muscular pain \& } \\
\text { swelling }\end{array}$} & Body-ache & Jiu dukheko \\
\hline & Muscular pain & Manspeshi haru dukheko \\
\hline & Sprain & Markeko \\
\hline & Strain & Tanaw bhayeko \\
\hline & Rheumatism & Baath bhayeko \\
\hline & Arthritis & Jorni dukheko \\
\hline & Headache & Tauko dukheko \\
\hline & Joint pain & Jorniharu dukheko \\
\hline & Swelling & Sunniyeko \\
\hline \multirow{2}{*}{$\begin{array}{l}\text { Cardiovascular } \\
\text { disorders }\end{array}$} & Cardiac tonic & Mutu lai tagat dine aushadhi \\
\hline & Blood pressure & Rakta chaap bhayeko \\
\hline \multirow[t]{9}{*}{ Others } & Fracture & Haadi bhachiyeko \\
\hline & Tonic & Tagat dine aushadhi \\
\hline & Lactation & Dudh badhaune \\
\hline & Easy delivery & Sajilai sutkeri garaune \\
\hline & Tumour & Mashu badheko \\
\hline & Diabetes & Chinirog/Madhumeh bhayeko \\
\hline & Cooling agent & Shitalta dine aushadhi \\
\hline & Stimulant & Uttejana badhaune aushadhi \\
\hline & Eye problems & Aankh ko rog \\
\hline
\end{tabular}

indica, Achyranthes aspera, Aegle marmelos, Aloe vera, Artemisia indica, Bauhinia variegata, Bombax ceiba, Calotropis gigantea, Carica papaya, Citrus limon, Colocasia esculenta, Coriandrum sativum, Curcuma amada, Cuscuta reflexa, Cynodon dactylon, Dalbergia sissoo, Datura metel, Dendrocalamus hamiltonii, Dioscorea pentaphylla, Ficus benghalensis, Gloriosa superba, Ipomoea aquatica, Ipomoea batatas, Ipomoea carnea Jacq. ssp. fistulosa, Lagenaria siceraria, Lepidium sativum, Linum usitatissimum, Malva parviflora, Mentha spicata, Mimosa 


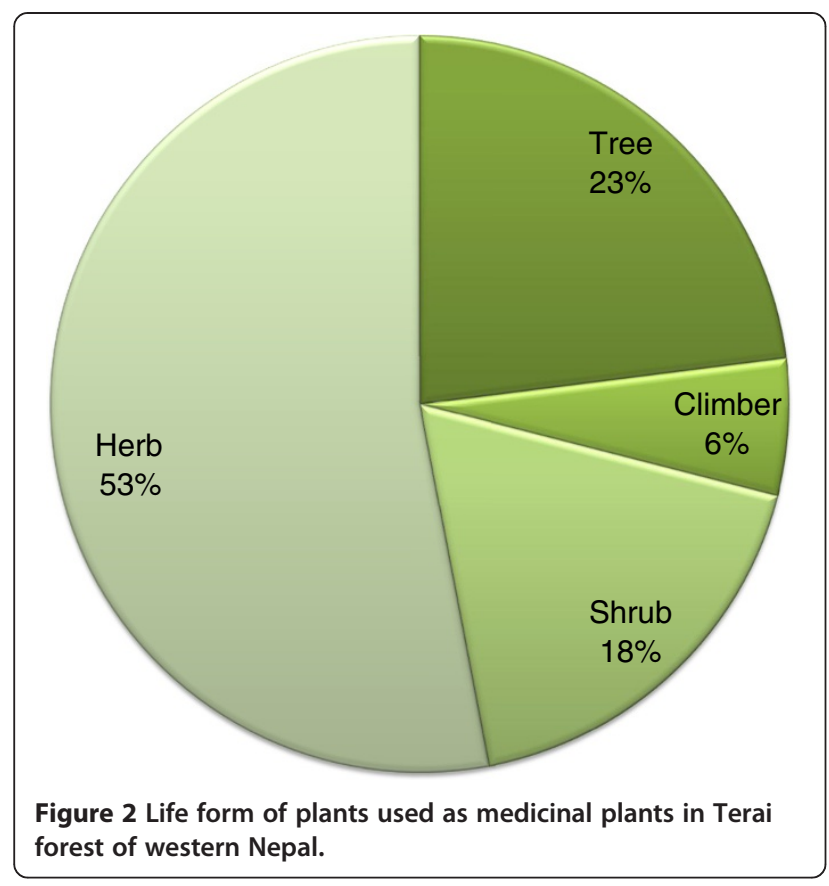

pudica, Mucuna pruriens, Phragmites vallatoria, Polygonum barbatum, Rauvolfia serpentina, Ricinus communis Shorea robusta, Solanum nigrum, Terminalia chebula, and Tribulus terrestris are reported for the first time in

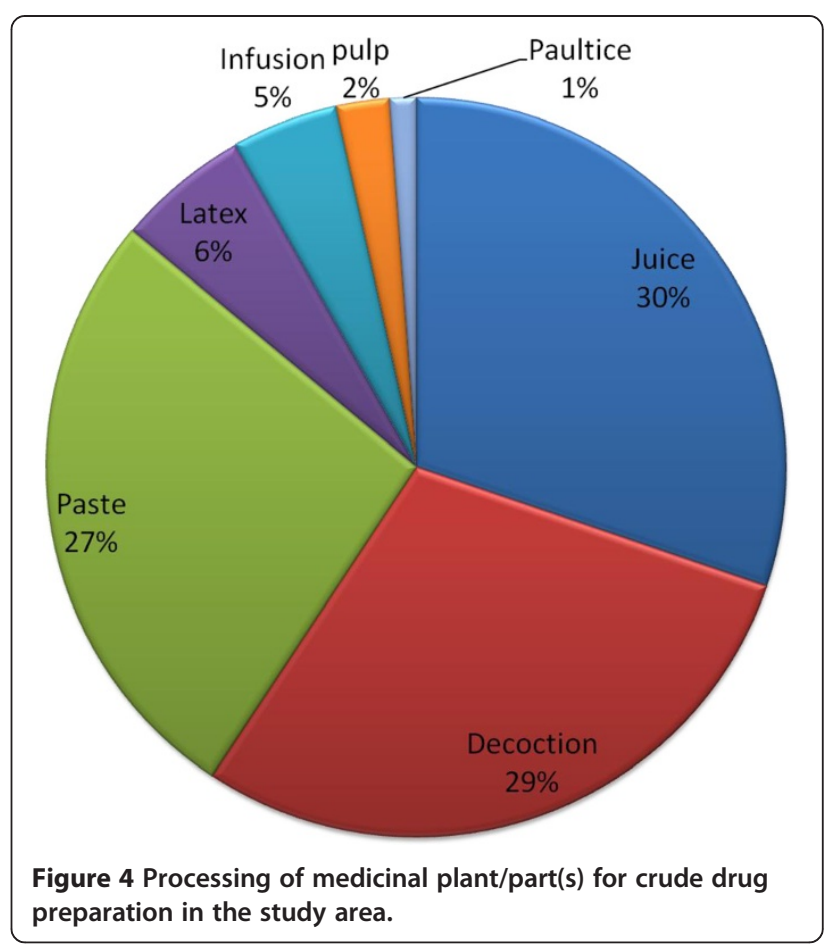

Nepal and adjoining areas of India. Some of the medicinal plants reported during the present study were reported for biological activities and bioactive constituents responsible

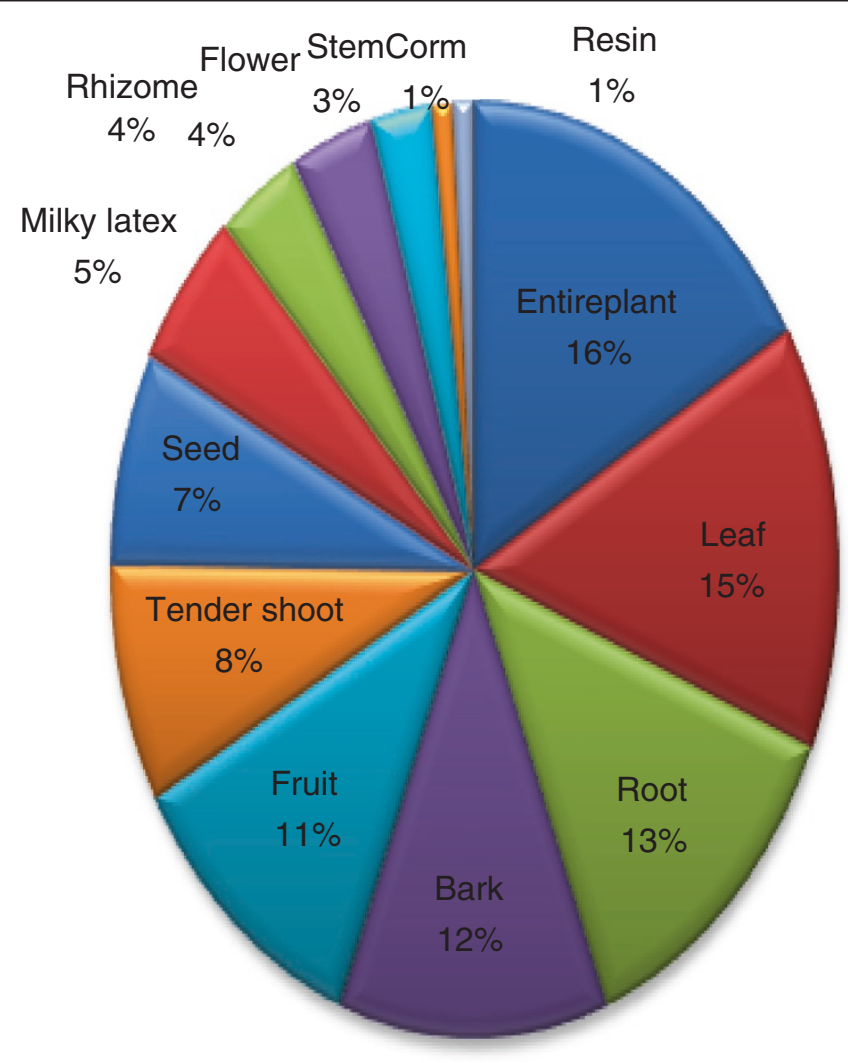

Figure 3 Plant parts used for the management of various healthcare problems in Terai forest of western Nepal. 
for their therapeutic properties $[7,17,46-50]$ which justify and validate the usages of these species for medicinal purposes in the study area.

\section{Consensus of agreement about uses of medicinal plants among informants}

To gain credibility, scientific studies that utilize traditional knowledge must be reliable. In ethnobotanical studies, consensus analysis provides a measure of reliability for any given claim providing reliable evidence. The product of $F_{I C}$ ranges from 0 to 1 . High value of $F_{I C}$ indicates the agreement of selection of taxa between informants, whereas a low value indicates disagreement [51]. Recently consensus analysis has been used as an important tool for the analysis of ethnobotanical data $[19,22,51-58]$. In the study area the informants' consensus about usages of medicinal plants ranges from 0.93 to 0.97 with an average value of 0.94 (Table 3), which shows high level of agreements among the informants. The high level of consensus among the informants about the usages of medicinal plants for the treatment and prevention of various diseases and ailments prevalent in the study area suggests that the ethnomedicinal uses of plants are currently in practice in the study area.

\section{Availability of medicinal plants in terai forest, conservation efforts and needs}

As for as availability of medicinal plants is concerned $39 \%$ medicinal plants are cultivated for food, fruit, spices and trade; thus are easily available for medicinal purposes. Majority of the $61 \%$ wild medicinal plant species are available without difficulty in the study area except Acacia catechu, Bacopa monnieri, Bombax ceiba, Drymaria diandra, Rauvolfia serpentina and Tribulus terrestris which are available with difficulty and needs to be conserved for future use. Unfortunately, neither local inhabitants nor Government is making serious efforts for conservation of medicinal plants in the study area. Unsustainable collection of generative and vegetative parts of medicinal plants from natural resources reduces their population as well as decrease multiplication and regenerative power. There is an urgent need to create awareness among the inhabitants of the study area about sustainable collection, conservation, domestication, small scale (home garden for personal use) as well as large scale (for trade) cultivation of medicinal plants. This will also improve the socio-economic condition of the inhabitants as well as reduce pressure on natural resources.

\section{Knowledge about traditional healing system and its transfer from one generation to other}

Bhagirathi Tharu, Mandali Tharu and Khadanand Poudyal are the main expert from the study area. These experts are working in this field since more than 30 years. Though there is a sub health post with less equipped facility in Shankar Nagar VDC and the modern hospital facilities are available in Butwal municipality which is near about $10 \mathrm{~km}$ far from Shankar Nagar VDC. The tribal people of the study area prefer traditional medicinal practice to the modern medicinal system because they know more about the medicinal plants which are easily available in their local area and herbal formulations are cooperatively cheaper and free from side effects. The tribal communities of the study area are not exception to the present stream of modernization and the traditional medicinal practice seems to be disappearing among the tribal communities of the study area. During present study it was found that the knowledge about utilization of medicinal plant species is generally accumulated by observation and experiences and transferred to the next generation by words of mouth. Our finding was similar to findings in other parts of India and abroad [24-30]. As indigenous knowledge on usages of medicinal plants is transmitted without any systematic process, and younger generations of the tribes are not interested in traditional healing system because it has no/ very little scope for money, so they engage themselves in other occupations. Thus, it is certain that such knowledge is at the risk of disappearance in the future [21].

\section{Conclusion}

Present study revealed that the local traditional healers of Rupandehi district, western Nepal are rich in ethnomedicinal knowledge and majority of people rely on plant based remedies for common health problems like headache, body ache, constipation, indigestion, cold, fever, diarrhea, dysentery, boils, wounds, skin diseases, urinary troubles, fractures, round worms, etc. The survey also revealed that all the traditional healers have strong faith on ethnomedicines although they were less conscious about the documentation and preservation of ethno medicinal folklore and medicinal plants. The group discussion and personal interviews show that youngsters of both Tharu and migrant society are less aware about the use of ethnomedicines; our findings are similar to reports from India [58]. On the other hand, traditional healers who are the main repository of ethno medicinal knowledge claim extreme secrecy over their ethnomedicinal knowledge. The traditional healers have strong believe that if they disclose the secrecy about the medicinal properties of particular plant all the medicinal potentialities of the plant will be lost and the remedy will not work properly.

Competing interest

The authors declare that they have no competing interests.

\section{Authors' contributions}

AGS, AK and DDT developed and designed the research study. AGS conducted field survey work, collected data and prepared draft of the 
manuscript. AK conducted statistical analysis and revised the manuscript. All authors have read and approved the final manuscript.

\section{Acknowledgement}

The authors are grateful to the Tharu tribal community and hilly migrants of study areas for sharing their indigenous knowledge throughout the field study, without their participation this research would not have been possible. AGS is also thankful to Dr. K. N. Poudyal, Herbalist, Shankar Nagar VDC for his help during the field study. The authors are also thankful to Editor-in-Chief Andrea Pieroni and three anonymous reviewers for their critical comments and useful suggestions on the previous version of the manuscript.

\section{Author details}

'Department of Botany, Butwal Multiple Campus, Tribhuvan University, Tribhuvan, Nepal. ${ }^{2}$ Eco-Auditing Group, CSIR-National Botanical Research Institute, Rana Pratap Marg, Lucknow 226001, India. ${ }^{3}$ Department of Botany, Maharani Lal Kunwari Post Graduate College, Balrampur, Uttar Pradesh, India.

\section{Received: 20 October 2011 Accepted: 29 April 2012}

Published: 16 May 2012

\section{References}

1. World Health Organization: General Guidelines for Methodologies on Research and Evaluation of Traditional Medicine. Geneva: WHO Switzerland; 2001.

2. Bhattarai S, Chaudhary RP, Taylor RSL: Ethnomedicinal plants used by the people of Manang district, central Nepal. J Ethnobiol Ethnomed 2006, 2:41.

3. Ghimire K, Bastakoti RR: Ethnomedicinal knowledge and healthcare practices among the Tharus of Nawalparasi district in central Nepal. Forest Ecol Manag 2009, 257:2066-2072.

4. Joshi K, Joshi AR: Indigenous knowledge and uses of medicinal plants by local communities of the Kali Gandaki Watershed Area, Nepal. J Ethnopharmacol 2000, 73:175-183.

5. Joshi K, Joshi R, Joshi AR: Indigenous knowledge and uses of medicinal plants in Macchegaun, Nepal. Indian J Tradit Know 2011, 10:281-286.

6. Kunwar RM, Uprety Y, Burlakoti C, Chaudhary CL, Bussmann RW: Indigenous Use and Ethnopharmacology of Medicinal Plants in Far-west Nepal. Ethnobot Res Appl 2009, 7:005-028.

7. Mahato RB, Chaudhary RP: Ethnomedicinal Study and Antibacterial activities of selected plants of Palpa district, Nepal. Scientific World 2003, 2:38-45.

8. Rajbhandari KR: Ethnobotany of Nepal. Nepal: Ethnobotanical Society of Nepal; 2001.

9. Manandhar NP: Ethnobotanical note on folk-lore medicines of Baglang district, Nepal. Contribution to Nepalese Studies 1993, 20(2):183-196.

10. Manandhar NP: A survey of medicinal plants of Jajarkot district, Nepal. J Ethnopharmacol 1995, 48:1-6.

11. Manandhar NP: Plants and People of Nepal. Oregon, USA: Timber Press Portland; 2002.

12. Manandher NP: Ethnobotanical census on herbal medicines of Banke district, Nepal. Contribution to Nepalese Studies 1998, 25:57-63.

13. Shrestha PM, Dhillion SS: Medicinal plant diversity and use in the highlands of Dolakha district, Nepal. J Ethnopharmaco/ 2003, 86:81-96.

14. Acharya KP, Acharya R: Ethnobotanical Study of Medicinal Plants Used By Tharu Community of Parroha VDC, Rupandehi District, Nepal. Scientific World 2009, 7(7):80-84.

15. Bhattarai NK: Traditional Medicine, Medicinal plants and biodiversity conservation in the global and Nepalese contexts. Plant Research 1998, 1:22-31.

16. Bhattarai S, Chaudhary RP, Taylor RSL: Ethno-medicinal Plants Used by the People of Nawalparasi District, Central Nepal. Our Nature 2009, 7:82-99.

17. Eigner D, Scholz D: Ferula asa-foetida and Curcuma longa in traditional medical treatment and diet in Nepal. J Ethnopharmacolo 1999, 67:1-6.

18. Rokaya MB, Munzbergovaa Z, Timsina B: Ethnobotanical study of medicinal plants from the Humla district of western Nepal. J Ethnopharmacol 2010, 130:485-504.

19. Uprety Y, Asselin H, Boon EK, Yadav S, Shrestha KK: Indigenous use and bio-efficacy of medicinal plants in the Rasuwa District. Central Nepal. J Ethnobiol Ethnomed 2010, 6:3.

20. Panthi MP, Chaudhary RP: Ethnomedicinal Plant Resources of Arghakhanchi District, West Nepal. Ethnobotany 2003, 15:71-86.
21. Bussmann RW, Sharon D: Traditional medicinal plant use in Northern Peru: tracking 2000 years of healing culture. J Ethnobiolo Ethnomed 2006, 2:47.

22. Kumar A, Pandey VC, Tewari DD: Documentation and determination of consensus about phytotherapeutic veterinary practices among the Tharu tribal community of Uttar Pradesh, India. Trop Anim Health Prod 2012, 44:863-872. DOl: 10.1007/s11250-011-9979-x

23. Kumar A: Ethnobotanical Aspects of Pharmacological Flora Used by Tharu Tribes in Terai Belt of North-Eastern Uttar Pradesh.: Dr. Ram Manohar Lohia Avadh University, 2004. Ph D Thesis.

24. Behera SK, Mishra MK: Indigenous phytotherapy for genito-urinary diseases used by the Kandha tribe of Orissa, India. J Ethnopharmacol 2005, 102:319-325.

25. Kumar A, Tewari DD, Pande YN: Ethnophytotherapeutics among Tharus of Beerpur Semara Forest range of Balrampur. J Econ Taxon Bot 2003, 27:839-844.

26. Longuefosse $\mathrm{J}$, Nossin E: Medical ethnobotany survey in Martinique. J Ethnopharmacolo 1996, 53:117-142.

27. Rajkumar N, Shivanna MB: Traditional herbal medicinal knowledge in Sagar taluk of Shimoga district, Karnataka, India. Indian J Nat Prod Res 2010, 1:102-108

28. Saikia AP, Ryakala VK, Sharma P, Goswami P, Bora U: Ethnobotany of medicinal plants used by Assamese people for various skin ailments and cosmetics. J Ethnopharmacol 2006, 106:149-157.

29. Rana MP, Sohel MSI, Akhter S, Islam MJ: Ethno-medicinal plants use by the Manipuri tribal community in Bangladesh. J Forestry Res 2010, 21:85-92.

30. Kumar A, Tewari DD, Pande YN: Indigenous and traditional herbal medicines from Gonad district of terai belt of north eastern Utter Pradesh. J Nat Con 2003, 15(1):261-268.

31. Anonymous: District Profile of Rupandehi. Nepal: District Development Committee Rupandehi; 2007.

32. Central Bureau of Statistics: Population of Nepal. Village Development Committees/Municipalities population census 2001.

33. Mc Lean J: Conservation and the impact of relocation on the Tharus of Chitwan, Nepal. Himalyan Research Bulletin 1999, XIX(2):38-44.

34. Martin GJ: Ethnobotany: A methods manual. London: Chapman and Hall; 1995.

35. Rao RR, Sharma BD: A Manual for Herbarium Collections. India: Botanica Survey of India; 1990

36. Woodland DW: Contemporary Plant Systematics. USA: Andrews University Press; 1997.

37. Press JR, Shrestha KK, Sutton DA: Annotated Checklist of the Flowering Plants of Nepal. London: The Natural History Museum; 2000.

38. Rao CK: Flora: A Gardener's Encyclopedia. India: Om Books Service; 2004

39. Ross IA: Medicinal Plants of the World. USA: Human Press; 1999.

40. Hara H: Stearn WT, Williams LHJ: An Enumeration of the Flowering Plants of Nepal, Volume I. London: British Museum of Natural History; 1978.

41. Hara H: Williams LHJ: An Enumeration of the Flowering Plants of Nepal, Volume II. London: British Museum of Natural History; 1979.

42. Hara H: Charter AO, Williams LHJ: An Enumeration of the Flowering Plants of Nepal, Volume III. London: British Museum of Natural History; 1982.

43. The International Plant Names Index (2008). http://www.ipni.org

44. Trotter R, Logan M: Informant consensus: a new approach for identifying potentially effective medicinal plants. In Plants in Indigenous Medicine and Diet: Biobehavioural Approaches. Edited by Etkin NL. Bedfort hills: Redgrave Publishers; 1986:91-112.

45. Heinrich M, Moerman ES, Leonti M: Ethnopharmacological field studies: A critical assessment of their conceptual basis and Methods. J Ethnopharmacolo 2009, 124:1-17.

46. Parekh J, Chanda SV: In vitro Antimicrobial Activity and Phytochemical Analysis of Some Indian Medicinal Plants. Turkish J Biology 2007, 31:53-58.

47. Samy RP, Ignacimuthu S, Raja DP: Preliminary screening of ethnomedicinal plants from India. J Ethnopharmacol 1999, 66:235-240.

48. Srinivasan D, Nathan S, Suresh T, Perumalsamy PL: Antimicrobial activity of certain Indian medicinal plants used in folkloric medicine. J Ethnopharmacol 2001, 74:217-220.

49. Wiedenfild H, Roader E: Pyrrolizedine alkaloid from Ageratum conyzoides. Planta Medica 1991, 57:578.

50. Chitravadivu C, Manian S, Kalaichelvi K: Qualitative Analysis of Selected Medicinal Plants, Tamilnadu, India. Middle-East J Scientific Research 2009, 4:144-146. 
51. Ragupathy S, Newsmaster SG, Murugesan M, Balasubramanium V, Muneer HUM: Consesensus of the Malasars traditional knowledge of medicinal plants in the Velliengiri holi hills India. J Ethnobiol Ethnomed 2008, 4:8.

52. Gazzaneo LRS, de Lucena RFP, de Albuquerque UP: Knowledge and use of medicinal plants by local specialists in a region of Atlantic Forest in the state of Pernambuco (Northeastern Brazil). J Ethnobiol Ethnomed 2005, 1:9.

53. Owuor BO, Kisangau DP: Kenyan medicinal plants used as antivenin: a comparison of plant usage. J Ethnobiol Ethnomed 2006, 2:7.

54. Kisangau DP, Lyaruu HVM, Hosea KM, Joseph CC: Use of traditional medicines in the management of HIV/AIDS opportunistic infections in Tanzania: a case in the Bukoba rural district. J Ethnobiol Ethnomed 2007, 3:29.

55. Garcia D, Domingues MV, Rodrigues E: Ethnopharmacological survey among migrants living in the Southeast Atlantic Forest of Diadema, São Paulo, Brazil. J Ethnobiol Ethnomed 2010, 6:29.

56. Cheikhyoussef A, Shapi M, Matengu K, Ashekele HM: Ethnobotanical study of indigenous knowledge on medicinal plant use by traditional healers in Oshikoto region. Namibia. Ethnobiol Ethnomed 2011, 7:10.

57. Ragupathy S, Newsmaster SG: Valorizing the 'Irulas' traditional knowledge of medicinal plants in the Kodiakkarai Reserve Forest India. J Ethnobiol Ethnomed 2009, 5:10.

58. Uniyal SK, Sharma S, Jamwal P: Folk Medicinal Practices in Kangra District of Himachal Pradesh, Western Himalaya. Human Ecol 2011, 39:479-488.

doi:10.1186/1746-4269-8-19

Cite this article as: Singh et al:: An ethnobotanical survey of medicinal plants used in Terai forest of western Nepal. Journal of Ethnobiology and Ethnomedicine 2012 8:19.

\section{Submit your next manuscript to BioMed Central and take full advantage of:}

- Convenient online submission

- Thorough peer review

- No space constraints or color figure charges

- Immediate publication on acceptance

- Inclusion in PubMed, CAS, Scopus and Google Scholar

- Research which is freely available for redistribution 